\title{
Biodiversity of the Phytoconstituents in the Some Plant Species Potentially Toxic
}

\section{Butnariu M *}

Banat's University of Agricultural Sciences and Veterinary Medicine, Calea Aradului, Timis, Romania

"Corresponding author: Monica Butnariu, Banat's University of Agricultural Sciences and Veterinary Medicine "Regele Mihai I al Romanei" Timisoara, Romania-300645, Calea Aradului 119, Timis, Romania, Tel: +40-0-256-277-464; E-mail: monicabutnariu@yahoo.com

Received date: February 20, 2017; Accepted date: February 25, 2017; Published date: March 03, 2017

Copyright: (c) 2017 Butnariu M. This is an open-access article distributed under the terms of the Creative Commons Attribution License, which permits unrestricted use, distribution, and reproduction in any medium, provided the original author and source are credited.

\section{Editorial}

List of the toxic plants, contains plants in which all of the plant or only certain parts of it are toxic. In general, poisoning occurs on the digestive system, but some plants, even by touch, may cause poisoning. Factors influencing the seriousness of intoxication are: Individual constitution, age, Characters inherited (hereditary inclination). At some plants, which contain a toxic labile, by boiling toxicity becomes inactive, it decomposes. Toxic plants in fairly high proportion negatively influence the quality. The species characterized from the viewpoint of chemical composition belong to classes such as the following.

\section{Aconitum Species}

\section{Phytoconstituents}

Aconitine, mesaconitine, lycoctonine and other alkaloids (2\% in tubers). Aconitum roots contain catecholamine alkaloids, quaternary ammonium compounds, isoquinolines and different biocompounds.

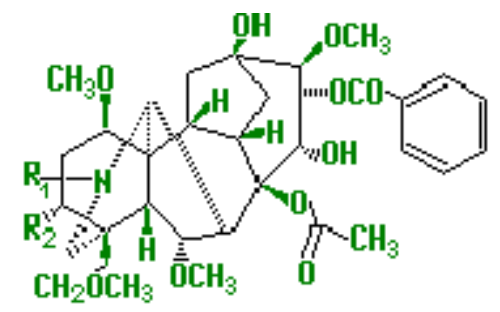

Mesaconitine: $\mathrm{R}_{1}-\mathrm{CH}_{3}$; $\mathrm{R}_{2}-\mathrm{OH} ; \mathrm{C}_{33} \mathrm{H}_{45} \mathrm{NO}_{11}$; CAS: 2752-64-9

Hypaconitine: $\mathrm{R}_{1}-\mathrm{CH}_{3} ; \mathrm{R}_{2}-\mathrm{H} ; \mathrm{C}_{33} \mathrm{H}_{45} \mathrm{NO}_{10}$; CAS: 6900-87-4

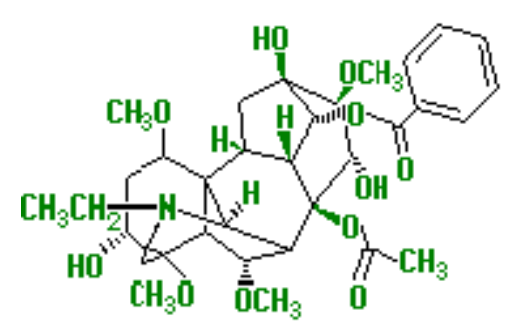

Aconitine: $\mathrm{R}_{1}-\mathrm{C}_{2} \mathrm{H}_{5} ; \mathrm{R}_{2}-\mathrm{OH} ; \mathrm{C}_{33} \mathrm{H}_{47} \mathrm{NO}_{11} ; \mathrm{CAS}: 302-27-2$

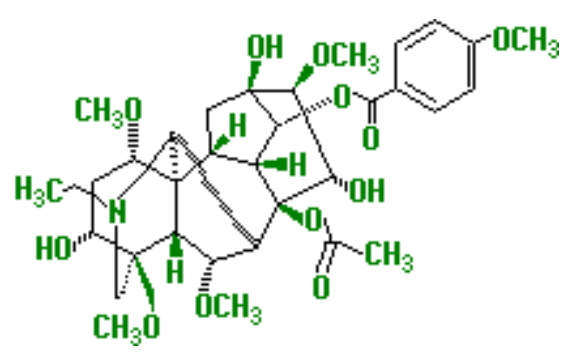

Jesaconitine: $\mathrm{C}_{35} \mathrm{H}_{49} \mathrm{NO}_{12}$; CAS: 16298-90-1

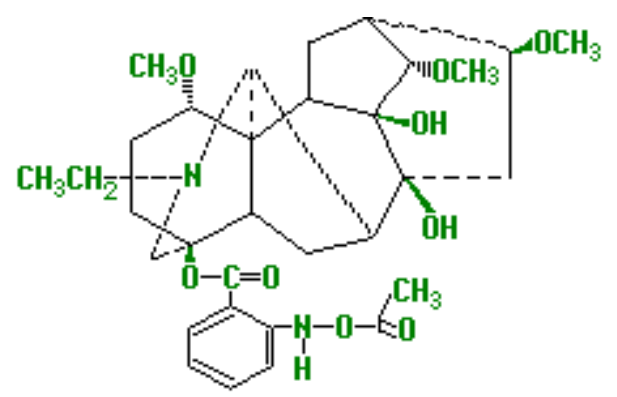

Lappaconitine: $\mathrm{C}_{32} \mathrm{H}_{44} \mathrm{~N}_{2} \mathrm{O}_{8}$; CAS: 32854-75-4

\section{Toxicity}

Main toxins, like aconitine, mesaconitine, jesaconitine and hypaconitine. The active principles are aconitine (a fast-acting toxin) and related alkaloids. Aconite extracts have been used homeopathically. Use is not recommended because of its toxicity. Aconitine and related alkaloids found in the Aconitum species are highly toxic, especially cardiotoxins or neurotoxins. The wild plant (roots or root tubers) is extremely toxic [1].

\section{Actaea spicata}

\section{Phytoconstituents}

Actaea spicata Linn. (Ranunculaceae) contents the benzylisoquinoline alkaloids (magnoflorine and corytuberine). 
<smiles>COc1ccc2c(c1O)-c1c(ccc(OC)c1O)CC2</smiles>

Magnoflorine: $\mathrm{C}_{20} \mathrm{H}_{24} \mathrm{NO}_{4}$; CAS: 2141-09-5<smiles>CNC1Cc2ccc(Cl)cc2-c2c(O)cc(C)cc21</smiles>

Corytuberine: $\mathrm{C}_{19} \mathrm{H}_{21} \mathrm{NO}_{4}$; CAS: 517-56-6

\section{Toxicity}

All parts, especially roots and berries, are toxic. As few as six berries have been reported to causesevere symptoms. Actaea species are closely related to plants in the genus Aconitum, a highly toxic plant genus which contains wolf bane and several varieties of monkshood. In some parts of Europe the powdered leaves, stems and flowers are used as an insecticide. Foliage and fruit are moderately toxic. Formerly protoanemonin was said to be found in fresh herb, but this couldn't be confirmed [2].

\section{Adonis vernalis, Adonis volgensis, Adonis aestivalis}

\section{Phytoconstituents}

Digitalis glycosides like adonidosid, adonivernosid, adonitoxine, cymarine, strophantidine, cardenolide glycosides; convallatoxin, glycosides-cymarine, adonitoxine; saponin phytosterine, adonite, adonitoxin and cardiac glycosides (cardenolides) similar to those of digitalis.

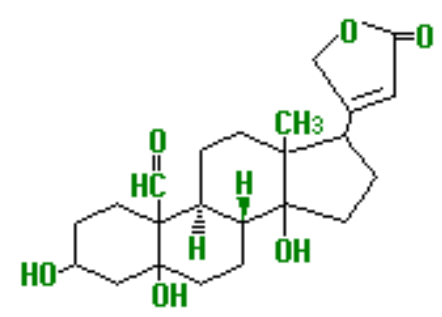

Strophantidine: $\mathrm{C}_{25} \mathrm{H}_{34} \mathrm{O}_{7}$; CAS: 66-28-4

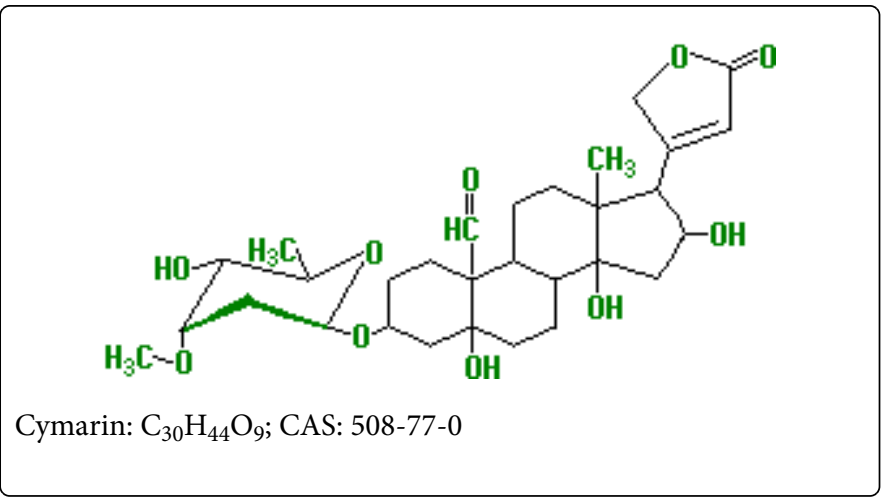

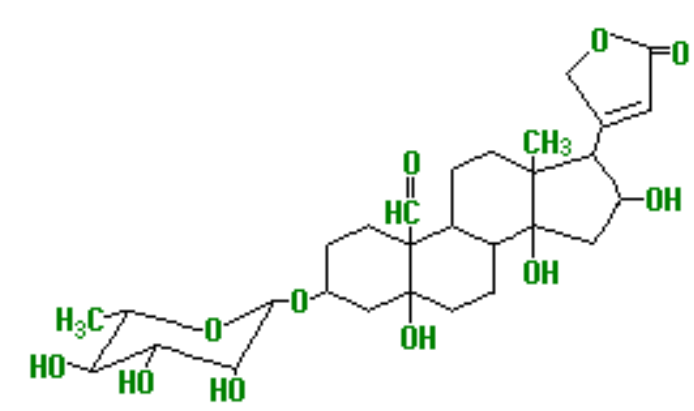

Adonitoxine: $\mathrm{C}_{29} \mathrm{H}_{42} \mathrm{O}_{10}$; CAS: 17651-61-5

\section{Toxicity}

This very toxic plant contains more than 10 cardiac glycosides. Its epigeous parts contain toxic cardiac glycosides; its roots are also poisonous, still being researched. Adonis first excites the inhibitory nerves in the heart at the central end, increasing arterial tension, and later paralyzes the peripheral end of the vagus. It also excites the accelerating nerves, so that there occurs an interference between the two systems of cardiac innervation, resulting in a feeble and irregular heart action and finally in a total paralysis of the motor nerve supply of the heart. It also causes diuresis. The action is rapid and not cumulative [3].

\section{Aethusa cynapium}

\section{Phytoconstituents}

Toxic concentrations of polynes also occur in Aethusa cynapium (fool's parsley) are also said to contain 'coniine-like volatile alkaloids'. Active ingredients: Online and cynopine, aethitsine, ethusanol; toxicity due to organic compounds polyines or polyacetylenes. Polyacetylens (aethusin, aethusanol A, B) and are known to contain several bioactive bisacetylenic alcohols.

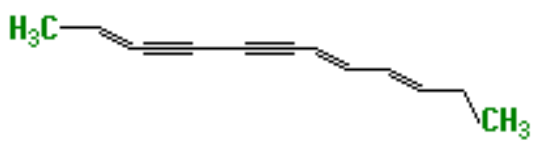

Aethusin: $\mathrm{C}_{13} \mathrm{H}_{14}$, CAS: 463-34-3 
<smiles>CCCCCCCCC(O)[C@H](O)CC#CC(=O)CC</smiles>

Panaxacol: $\mathrm{C}_{16} \mathrm{H}_{23} \mathrm{O}_{2}$, CAS: 106828-96-0

\section{Toxicity}

Aethusin, related to cicutoxin.Although fairly toxic, fool's parsley has occasionally been used in folk medicine. The herb is sedative and stomachic. It has been used in the treatment of gastro-intestinal problems, especially in children, and also to treat convulsions and summer diarrhoea. Extreme caution in the use of this herb is advised; see the notes above on toxicity. Excitement on ingestion, then depression, paralysis of skeletal muscles, vomiting, diarrhoea, pupils dilated, death by suffocation, does not affect the heart. The roots mistaken for radish, leaves for Parsley. Aethusa chiefly affects nervous system/gastrointestinal system. It is used to treat violent vomiting, pains, convulsions, and even delirium, which all lead to exhaustion and sleepiness. This remedy is also used to strengthen the mind when it is weak and when concentration is difficult [4].

\section{Agrostemma githago}

\section{Phytoconstituents}

The toxin is primarily sapogenin githagenin (may be $5-7 \%$ of the weight of seeds). Sapogenin githagenin (agrostemmasaponins) is contained in seeds and amounts to 5-7\% of their weight. Agrostin (lectin) and triterpenic saponins: githagenin (7\%); agrostemmic acid (diureidoacetate or diureidoacetate).

\section{Toxicity}

Githagenin is toxic (destroyed at $50^{\circ} \mathrm{C}$ ). This plant contains colloidal glycosides which contain the properties of saponin. Saponincontaining plants have a bitter taste and are not often eaten, but there have been reports of poisoning in horses. $3 \mathrm{~g}$ [of seeds] are considered toxic. The seeds are primarily responsible for poisonings from corncockle, however, all parts are suspected to be toxic.

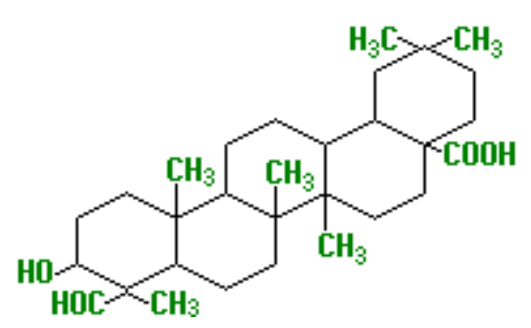

Githagenin: $\mathrm{C}_{30} \mathrm{H}_{46} \mathrm{O}_{4}$; CAS: 639-14-5<smiles>NC(=O)NC(NC(N)=O)C(=O)O</smiles>

Allantoic acid: $\mathrm{C}_{4} \mathrm{H}_{8} \mathrm{~N}_{4} \mathrm{O}_{4}$; CAS: 99-16-1<smiles>NC(=O)NC1NC(=O)NC1=O</smiles>

Allantoin: $\mathrm{C}_{4} \mathrm{H}_{6} \mathrm{~N}_{4} \mathrm{O}_{3}$; CAS: 97-59-6

Seeds consumed at a concentration of $0.2-0.5 \%$ of body weight are lethal to young poultry; older birds are less susceptible. The toxic response includes severe gastroenteritis, acute stomach pain, vomiting, diarrhea, dizziness, listlessness, weakness, and slows breathing [5].

\section{Ailanthus altissima}

\section{Phytoconstituents}

The root bark and stem bark contain quassinoids: ailanthone, ailanthinone, chaparrin, glaucarubol, glaucarubin, glaucarubinone, shinjudilactone, quassine, neoquassine, shinjulactones, ailantinols, quassinoid I, shinjuglycosides $1 \alpha, 11 \alpha$-epoxy- $2 \beta, 11 \beta, 12 \beta, 20$ tetrahydroxypicrasa-3,13-(21)-dien-16-one, $1 \alpha, 11 \alpha$-epoxy- $2 \beta, 11 \beta, 12 \alpha$, 20-tetrahydroxypicrasa-3,13-(21)-dien-16-one; alkaloids: canthin-6one, 1-methoxycanthin-6-one, 1-hydroxycanthin-6-one, canthin-6one-3N-oxide, 5-hydroxymethylcanthin-6-one, 1-(1,2dihydroxyethyl)-4-methoxy- $\beta$-carboline, $\quad \beta$-carboline-1propionic acid, 1-carbamoyl- $\beta$-carboline, 1 -carbomethoxy- $\beta$ carboline; coumarins: scopoletin, isofraxidin, altissimacoumarins A, B. The wood contains alkaloids: canthin-6-one, 1-methoxycanthin-6-one, canthin-6-one-3N-oxide.

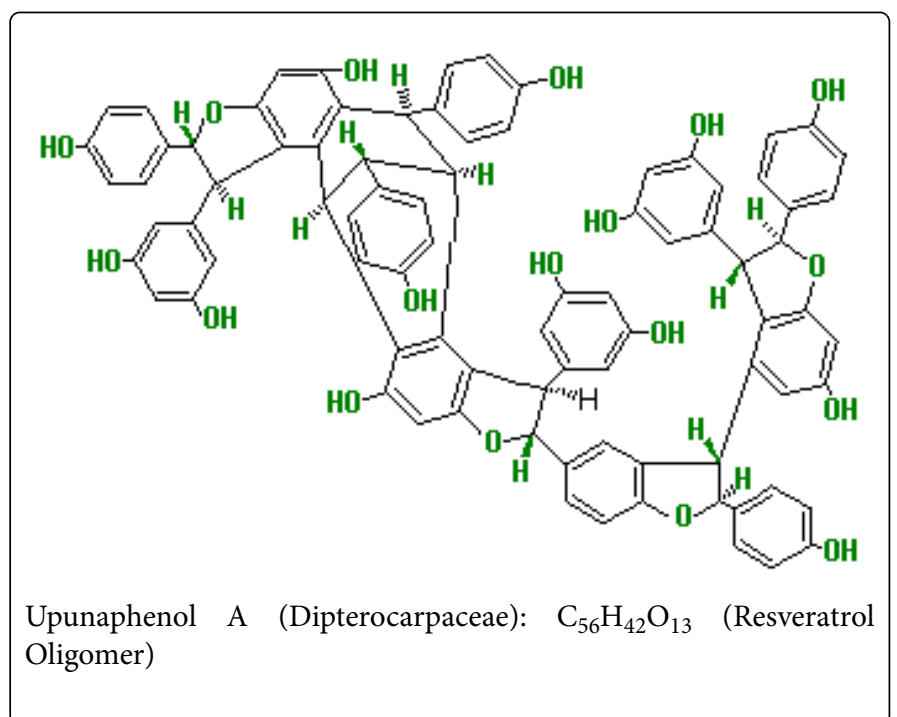


Citation: Butnariu M (2017) Biodiversity of the Phytoconstituents in the Some Plant Species Potentially Toxic. J Biodivers Endanger Species 5:<smiles>Cc1cc2ccc(=O)oc2cc1O</smiles>

Scopoletin: $\mathrm{C}_{10} \mathrm{H}_{8} \mathrm{O}_{4}$, CAS 92-61-5<smiles>O=c1ccc2nccc(-c3ccccc3)c2[nH]1</smiles>

Canthin-6-one: $\mathrm{C}_{14} \mathrm{H}_{8} \mathrm{~N}_{2} \mathrm{O}_{2}$, CAS: 75969-83-4<smiles>COc1cc2ccc(=O)oc2c(OC)c1O</smiles>

Isofraxidin: $\mathrm{C}_{11} \mathrm{H}_{10} \mathrm{O}_{5}$, CAS: 486-21-5

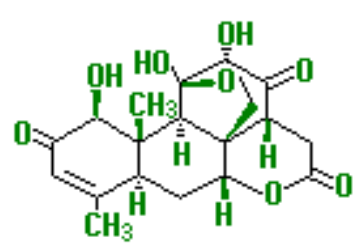

Ailanthone: $\mathrm{C}_{20} \mathrm{H}_{24} \mathrm{O}_{7}$; CAS: 981-15-7

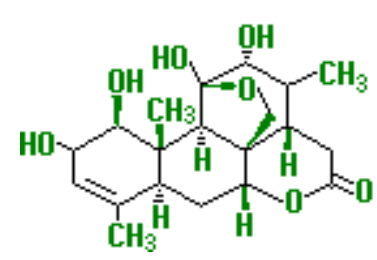

Chaparrin: $\mathrm{C}_{20} \mathrm{H}_{28} \mathrm{O}_{7}$; CAS: 4616-50-6

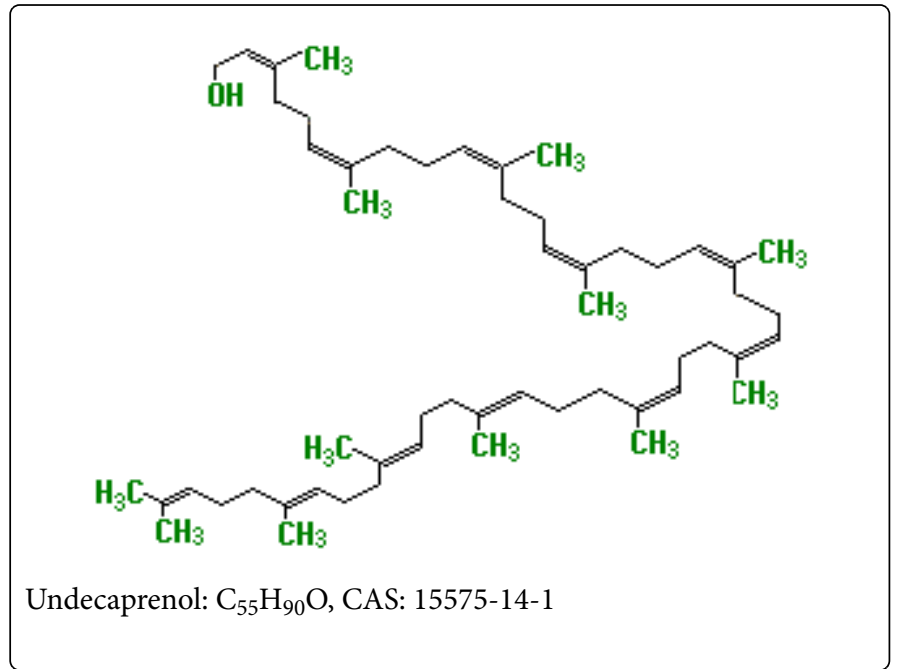<smiles>Cc1ccc(C(=O)Nc2ccccc2C(=O)O)o1</smiles>

Ailanthinone: $\mathrm{C}_{13} \mathrm{H}_{11} \mathrm{NO}_{4}$; CAS: 423729-45-7

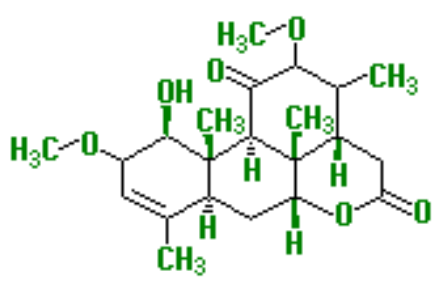

Quassine: $\mathrm{C}_{22} \mathrm{H}_{28} \mathrm{O}_{6}$, CAS: 76-78-8

Seed contains quassinoids: shinjuglycosides A, B, C, D; sterols: ailanthusterols $\mathrm{A}$ and B. Leaf contains alkaloids: canthin-6-one, 1methoxycanthin-6-one, 4-methoxy-1-vinyl- $\beta$-carboline, 1 methoxycarbonyl- $\beta$-carboline; flavonoids: apigenin, kaempferol, quercetin, isoquercetin, rutin, luteolin 7-O- $\beta$ - $(6$ "-galloyl glucopyranoside) or $12 \%$ tannin, quercetin, as well as isoquercetin, and alkaloid linuthine. Leaves/wood are high in cellulose and are used in paper-making. The crushed leaves and flowers are insect-repellent. The parts, when steeped in water, are said to yield an insecticidal solution. An aqueous extract of leaves contains a substance that is toxic to other tree seedlings.

\section{Toxicity}

Leaves are toxic to domestic animals. Gardeners who fell the tree may suffer rashes. Observations are more violent than my own to sniffing the leaves, "The odour of the foliage is intensely disagreeable and can cause headache and nausea rhinitis and conjunctivitis. The pollen can cause hay fever" The sap is a skin and eye irritant. Pollen can cause allergic reactions. A yellow dye is obtained from the leaves. 
Male flowers are conspicuous and ill smelling, attracting many insects. Female flowers are less odorous and less conspicuous [6].

\section{Allium Species}

\section{Phytoconstituents}

The bulb contains sulfur compounds: alliin, cycloalliin, isoalliin, allicin, dipropenyl disulfide, methylpropenyl disulfide, dipropyl trisulfide, dimethyl thiophene, L- $\gamma$-glutamyl-S-(1E)-1-propenyl-Lcysteine, propanethiol, 3-mercapto-2-methylpentan-1-ol; S-propenylL-cysteine sulfoxide, anthocyanins: peonidin-3,5 diglucoside, cyaniding-3,5-diglucoside, cyaniding-3-glucoside; Se"alliins": selenomethionine, selenocysteine, Se-methylselenocysteine; flavonoids: spiraeoside, quercetin, quercetin-3,4'-diglucoside, isorhamnetin-4'-glucoside, isorhamnetin-3,4'-diglucoside, kaempferol-4'-glucoside, quercetin-3,7,4'-triglucopyranoside, kaempferol-3-sophoroside-7-glucuronide, quercetin-3-sophoroside-7glucuronide. The bulb also contains allicepin and protocatechuic acid.<smiles>C=CCS(=O)C[C@H](N)C(=O)O</smiles>

Alliin: $\mathrm{C}_{6} \mathrm{H}_{11} \mathrm{NO}_{3}$ S; CAS: 556-27-4<smiles>CC1CN(C)C(C(=O)O)C(=S)N1</smiles>

Cycloalliin: $\mathrm{C}_{6} \mathrm{H}_{11} \mathrm{NO}_{3} \mathrm{~S}$, CAS: 455-41-4

$$
\mathrm{H}_{3} \mathrm{C} \sim \mathrm{S} \sim \mathrm{S} \sim \mathrm{CH}_{3}
$$

Dipropenyl disulfide, $\mathrm{C}_{6} \mathrm{H}_{10} \mathrm{~S}_{2}$; CAS: 2179-57-9.<smiles>C[Se]CCC(N)C(=O)O</smiles>

Selenomethionine: $\mathrm{C}_{5} \mathrm{H}_{11} \mathrm{NO}_{2} \mathrm{Se}$; CAS: 1464-42-2

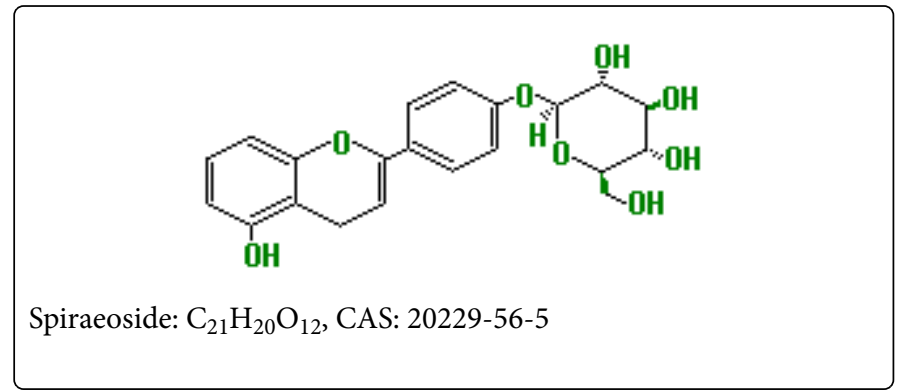<smiles>O=C(O)c1ccc(O)c(O)c1</smiles>

Protocatechuic acid: $\mathrm{C}_{7} \mathrm{H}_{6} \mathrm{O}_{4}$, CAS: 99-50-3

\section{Toxicity}

Calcium oxalate and possibly irritant proteins. Nevertheless, ingestion of onion and other Allium sp. are known to be toxic to many animal species, including dogs, cats, cattle, horses, sheep and goats. The signs pain and swelling of oral cavity, acute inflammation of oropharynx accompanied by salivation, pawing at the mouth, and drooling. Edema of the lips, tongue, and throat may be seen. Allium sp. contain organosulfoxides, particularly alk(en)yl cysteine sulfoxides, are responsible for their characteristic odor. Plants trauma, like chewing or cutting, converts the organosulfoxides to a complex mixture of sulfurcontaining organic compounds that are responsible for the flavor and effects of these plants on animals. Allium organosulfur compounds appear to be readily absorbed through the gastrointestinal tract and are metabolized to highly reactive oxidants, have been implicated in onion-induced hemolytic anemia [7].

\section{Ambrosia Species}

\section{Phytoconstituents}

The main components in the total extract are phenolcarboxylic acids (ferulic, isoferulic, caffeic, chlorogenic acids and caffeic acid glycoside) coumarins (scopoletin, scopolin, esculetin, esculin, umbelliferone, skimmin), and flavonoids (jaceidin, quercetin, isorhamnetin, isorhamnetin-3-rutinoside, quercimeritrin, isoquercitrin, and glycosides of xanthomicrol and 4', 5-dihydroxy-3,6,7,8tetramethoxyflavone). Pseudoguaianolides also have skeleton of bicycle decane to which is associated a g-lactonic ring, have a b-methyl group at C-5 position and are classified as ambrosanolides and helenanolides according to stereochemistry of methyl group at C10; in other words, ambrosanolides have b-methyl and helenanolides an amethyl in this position. Polymethoxylated flavonoids have been identified in ambrosia: jaceidin (5,7,4'-trihydroxi-3,6,3'trimethoxyflavone), $\quad$ xanthomicrol $\quad\left(4^{\prime}, 5\right.$-dihydroxy-6,7,8trimethoxyflavone), 4',5-dihydroxy-3,6,7,8-tetramethoxyflavone, and their glycosides. Sesquiterpene: chloroambrosin, ambrosin, damsin, neoambrosin, farnserin, hymenolin, hymenin, stamonin-b, anhydrofarnserin; triterpenes: s-amyrin; flavonoids: apigenin; 
Citation: Butnariu M (2017) Biodiversity of the Phytoconstituents in the Some Plant Species Potentially Toxic. J Biodivers Endanger Species 5: e127. doi:10.4172/2332-2543.1000e127

Page 6 of 9

coumarins; sterols: ß-sitosterol; tannin; and volatile oil: carvone, camphor, caryophyllene, cineole.<smiles></smiles>

Skimmin: $\mathrm{C}_{15} \mathrm{H}_{16} \mathrm{O}_{8}$, CAS: 93-39-0

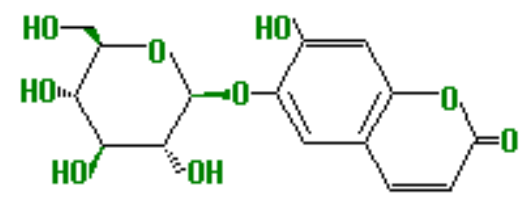

Esculin: $\mathrm{C}_{15} \mathrm{H}_{16} \mathrm{O}_{9}$, CAS: 531-75-9<smiles>COc1cc2ccc(=O)oc2cc1O</smiles>

Scopoletin: $\mathrm{C}_{10} \mathrm{H}_{8} \mathrm{O}_{4}$, CAS: 92-61-5<smiles>COc1cc2ccc(=O)oc2cc1O</smiles>

Scopolin: $\mathrm{C}_{16} \mathrm{H}_{18} \mathrm{O}_{9}$, CAS: 531-44-2

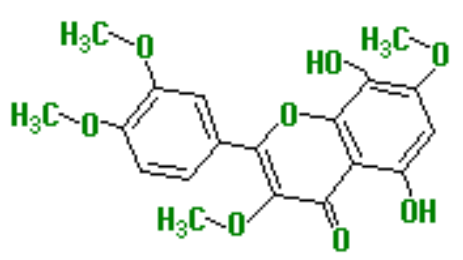

4,5-dihydroxy-3,6,7,8-tetramethoxyflavone, $\quad \mathrm{C}_{19} \mathrm{H}_{18} \mathrm{O}_{8}, \quad$ CAS: 28914-17-2<smiles></smiles>

Isorhamnetin-3-O-glucoside: $\mathrm{C}_{22} \mathrm{H}_{22} \mathrm{O}_{12}$, CAS: 5041-82-7

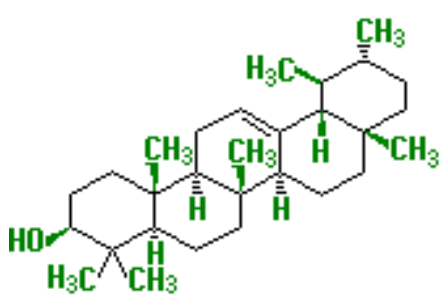

S-amyrin: $\mathrm{C}_{30} \mathrm{H}_{50} \mathrm{O}$, CAS: 559-70-6

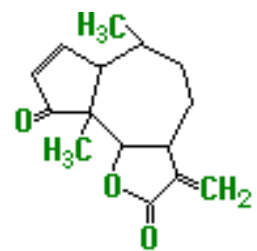

Damsin (ambrosin): $\mathrm{C}_{15} \mathrm{H}_{20} \mathrm{O}_{3}$, CAS: 1216-42-8<smiles>Nc1cc(-c2c[nH]c(=O)c3[nH]c(Br)cc23)c[nH]1</smiles>

Hymenin: $\mathrm{C}_{11} \mathrm{H}_{11} \mathrm{Br}_{2} \mathrm{~N}_{5}$, CAS: 105748-62-7

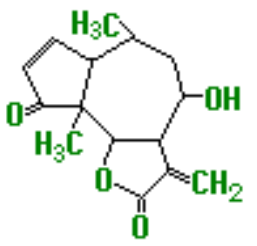

Carpesiolin: $\mathrm{C}_{15} \mathrm{H}_{20} \mathrm{O}_{4}$, CAS: 2004-10-25 
<smiles></smiles>

Jaceidin: $\mathrm{C}_{18} \mathrm{H}_{16} \mathrm{O}_{8}$, CAS: 10173-01-0<smiles>COC(=C1Oc2c(OC)c(OC)c(OC)c(OC)c2C1=O)c1ccc(O)cc1</smiles>

Xanthomicrol: $\mathrm{C}_{18} \mathrm{H}_{16} \mathrm{O}_{7}$, CAS: 16545-23-6<smiles>O=c1ccc2ccc([Hg])cc2o1</smiles>

Umbelliferone: $\mathrm{C}_{9} \mathrm{H}_{6} \mathrm{O}_{3}$, CAS: 93-35-6<smiles>O=c1ccc2cc(Br)c([Hg])cc2o1</smiles>

Esculetin: $\mathrm{C}_{9} \mathrm{H}_{6} \mathrm{O}_{4}$, CAS: 305-01-1

\section{Toxicity}

Ambrosia sp., both in their native range and in invaded areas, are of public health concern due to the allergenic properties of their pollen. The NDA panel concluded that inhalation of plant pollen causes rhinoconjunctivitis and asthma, with skin allergies and food allergy playing minor roles. Ambrosia may cross-sensitize patients to other allergens, including food allergens [8].

\section{Andromeda polifolia}

\section{Phytoconstituents}

Gardenoside, guaijaverine and avicularine, a new flavonoldipentoside named polifolioside, neurotoxic diterpenoids: andromedotoxin and grayanotoxin.<smiles>O=c1c(O[C@@H]2O[C@H](CO)[C@@H](O)[C@H]2O)c(-c2ccc(O)c(O)c2)oc2cc(O)cc(O)c12</smiles>

Guajavarin: $\mathrm{C}_{20} \mathrm{H}_{18} \mathrm{O}_{11}$, CAS: 22255-13-6<smiles></smiles>

Avicularin: $\mathrm{C}_{20} \mathrm{H}_{18} \mathrm{O}_{11}$, CAS: 572-30-5

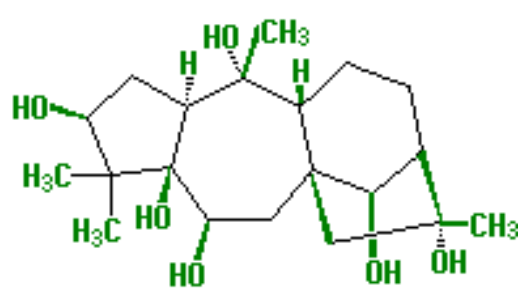

Grayanotoxin: $\mathrm{C}_{20} \mathrm{H}_{34} \mathrm{O}_{6}$, CAS: 4678-45-9

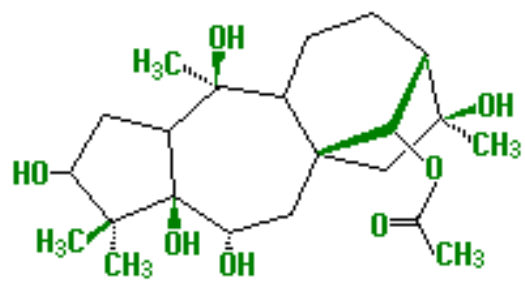

Andromedotoxin: $\mathrm{C}_{20} \mathrm{H}_{34} \mathrm{O}_{6}$, CAS: 4720-09-6

\section{Toxicity}

These toxins occur throughout the plant, including the nectar, and can be found in honey. The leaves of most of these species are leathery or bitter, so their palatability is rather low. No specific antidote is known but subcutaneous injection of morphine has been used successfully in goats. A toxin, called 'andromedotoxin' can be released from the plant if it is infused in boiling water. See notes below regarding use of the plant for tea [9]. 
Citation: Butnariu M (2017) Biodiversity of the Phytoconstituents in the Some Plant Species Potentially Toxic. J Biodivers Endanger Species 5:

\section{Anemone Species}

\section{Phytoconstituents}

Ranunculin is converted enzymatically to protoanemonin. The rhizome contains triterpenoid saponins: raddeanins $\mathrm{A}, \mathrm{B}, \mathrm{C}, \mathrm{D}, \mathrm{E}, \mathrm{F}$, raddeanosides $R_{0}, R_{2} \ldots R_{18}$, hederasaponin $B$, eleutheroside $K$, hederacholichiside F, leontoside $\mathrm{D}$; triterpenoids: oleanolic acid, acetyloleanolic acid, betulin, betulic acid, lupeol; lactone: ranunculin. The aerial part also contains raddeanin $\mathrm{A}$.

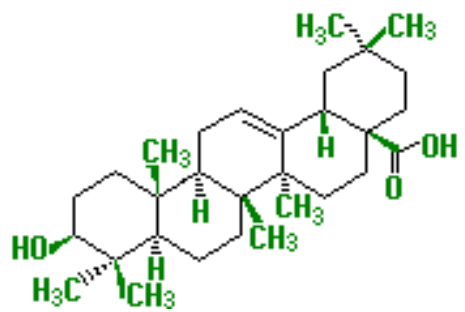

Oleanolic acid: $\mathrm{C}_{30} \mathrm{H}_{48} \mathrm{O}_{3}$, CAS: $508-02-1$

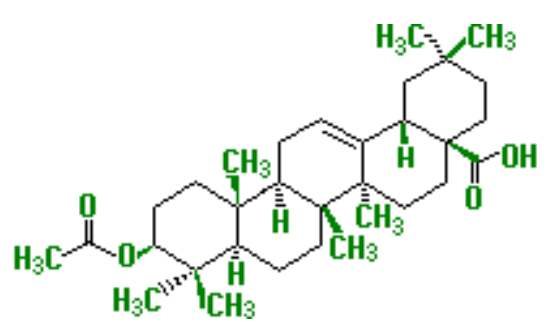

Acetyloleanolic acid: $\mathrm{C}_{32} \mathrm{H}_{50} \mathrm{O}_{4}$, CAS: 4339-72-4

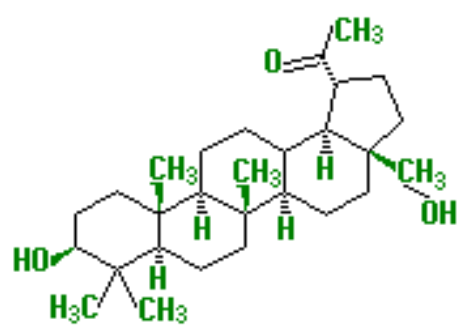

Betulin: $\mathrm{C}_{30} \mathrm{H}_{50} \mathrm{O}_{2}$, CAS: 473-98-3

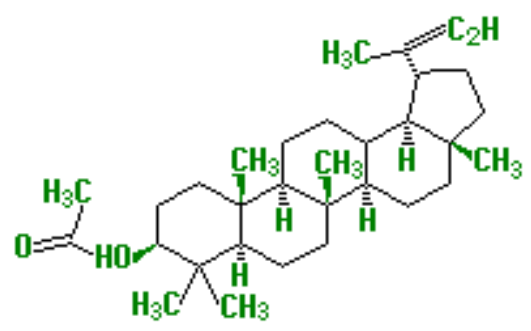

Lupeol: $\mathrm{C}_{32} \mathrm{H}_{52} \mathrm{O}_{2}$, CAS: 1617-68-1

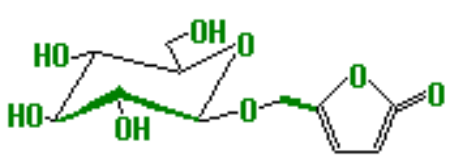

Ranunculin: $\mathrm{C}_{11} \mathrm{H}_{16} \mathrm{O}_{8}$, CAS: 89412-79-3<smiles>C=C1CC=C(C=O)O1</smiles>

Protoanemonin: $\mathrm{C}_{5} \mathrm{H}_{4} \mathrm{O}_{2}$, CAS: 108-28-1

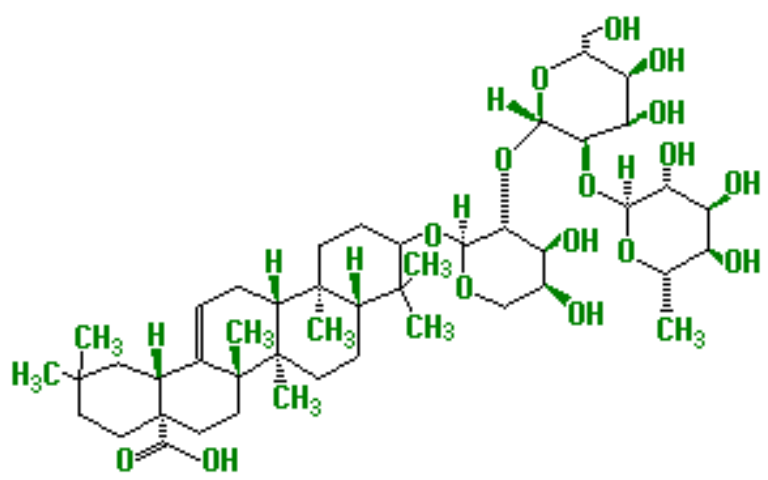

Raddeanin A: $\mathrm{C}_{47} \mathrm{H}_{76} \mathrm{O}_{16}$, CAS: 89412-79-3

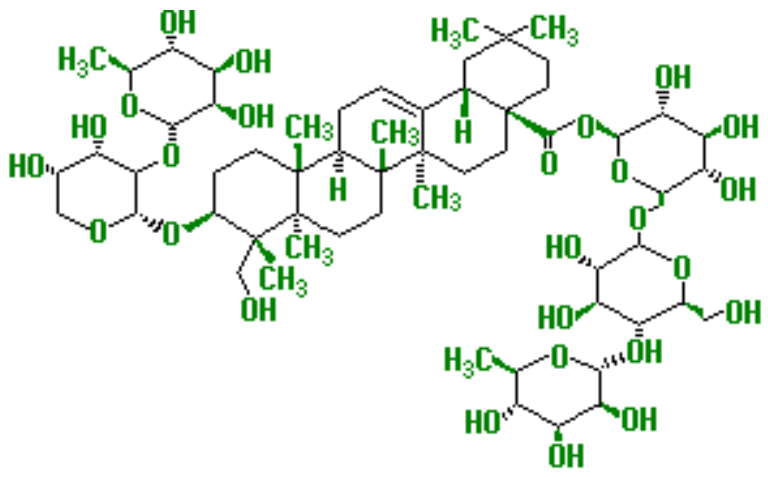

Hederasaponin B: $\mathrm{C}_{59} \mathrm{H}_{96} \mathrm{O}_{26}$, CAS: 14216-03-6

\section{Toxicity}

The toxin (protoanemonin) is quite irritating to mucous membranes. Blisters are commonly seen after the plant is chewed. Ingestion is rare. If ingested, signs of severe, hemorrhagic gastroenteritis are seen and may lead to shock [10].

Chemical structure diversity and their biodiversity some the plants in overview of the extremely various. Plants are a rich source of bioactive phytochemicals or bio nutrients and on toxicity of active plant principles, which must be known, to determine their safety use. 
Citation: Butnariu M (2017) Biodiversity of the Phytoconstituents in the Some Plant Species Potentially Toxic. J Biodivers Endanger Species 5: e127. doi:10.4172/2332-2543.1000e127

Page 9 of 9

Additionally many others, this list do not exhaust all toxic plants (Only some of species beginning with the letter A).

\section{References}

1. Turabekova MA, Rasulev BF (2005) QSAR analysis of the structure-toxicity relationship of aconitum and delphinium diterpene alkaloids. Chemistry of Natural Compounds, Springer 41: 213-219.

2. Ikezawa NI, Sato KF (2008) Molecular Cloning and Characterization of CYP80G2, a Cytochrome P450 That Catalyzes an Intramolecular C-C Phenol Coupling of (S)-Reticuline in Magnoflorine Biosynthesis, from Cultured Coptis japonica Cells. J Biol Chem 283: 8810-8821.

3. Woods LW, George LW, Anderson ML, Woods DM, Filigenzi MS, et al. (2007) Evaluation of the toxicity of Adonis aestivalis in calves. J Vet Diagn Invest 19: 581-585.

4. Madaan R, Kumar S, Bansal G, Sharma A (2011) Plant Drugs Used to Combat Menace of Anxiety Disorders. Pharmacogn Commun 1: 1-51.
5. Al Nimer MS, Al Deen SM, Lateef AZW, Al Kayar IT (2011) Magnetized water induces changes in the antioxidant properties of some medicinal plants extracts. Int J Green Pharm 5: 145-148.

6. Schall MJ, Davis DD (2009) Ailanthus altissima Wilt and Mortality: Etiology. Plant Dis pp: 747-751.

7. Zhang Y (2006) Onion, a vegetable as well as a medicine. Health Preserving 27: $\mathrm{p} 635$.

8. Vitalos M, Karrer G (2009) Dispersal of Ambrosia artemisiifolia seeds along roads: the contribution of traffic and mowing machines. In: Biological Invasions: Towards a Synthesis. J Neobiota 8: 53-60.

9. Pojar J, MacKinnon A (2004) Plants of the Pacific Northwest Coast. Vancouver: Lone Pine Publishing p: 53.

10. Xia ZT, Liu DY, Wang XY, Liu KF, Zhang PC (2004) Studies on the chemical constituents of Anemone raddeana Regel. Acta Chimica Sinica 62: 1935-1940. 